\title{
MRlgFUS in the treatment of spontaneous intracerebral hemorrhage
}

\author{
Leodante da Costa ${ }^{1 *}$, Nir Lipsman², Allison Bethune ${ }^{2}$, Todd Mainprize ${ }^{2}$, Kullervo Hynynen ${ }^{1}$ \\ From Current and Future Applications of Focused Ultrasound 2014. 4th International Symposium \\ Washington, D.C, USA. 12-16 October 2014
}

\section{Background/introduction}

Spontaneous cerebral hemorrhage (ICH) is a major cause of mortality and morbidity worldwide. Although the mechanisms leading to ICH are relatively well known, little improvement in outcomes has occurred over the years, in spite of significant advances in surgical techniques and medical management options. Evidence is available to suggest that liquefying and/or removing the clot after ICH might be beneficial. The objective of this work is to test the feasibility of use of MRI guided focused ultrasound (MRgFUS) in the treatment of $\mathrm{ICH}$. Our hypotheses are that MRgFUS can be used safely to effectively cause clot lysis and it will provide good radiological resolution of $\mathrm{ICH}$.

\section{Methods}

At least 6 patients with a recent $(<72 \mathrm{~h}) \mathrm{ICH}$ and hematoma $>2 \mathrm{~cm}$ will be recruited. MRgFUS will be used to sonicate the clot leading to lysis. Except for the MRgFUS treatment, $\mathrm{ICH}$ patients will receive the same treatment as those not in the trial. Stereotactic aspiration can be added if deemed safe by the treating neurosurgeon. The primary outcome is feasibility (statistical analysis is not proposed); adverse events will be examined and analyzed. Secondary end point is the radiological progression of the clot.

\section{Results and conclusions}

We expect that MRgFUS be feasible and safe, and clot size reduction will be seen in most patients. It's possible that the procedure could have some therapeutic value for subjects with few or no other options for treatment.

\section{Authors' details \\ ${ }^{1}$ Sunnybrook Research Institute, Toronto, Ontario, Canada. ${ }^{2}$ Sunnybrook} Health Sciences Centre, Toronto, Ontario, Canada.

${ }^{1}$ Sunnybrook Research Institute, Toronto, Ontario, Canada

Full list of author information is available at the end of the article
Published: 30 June 2015

doi:10.1186/2050-5736-3-S1-07

Cite this article as: da Costa et al:: MRlgFUS in the treatment of

spontaneous intracerebral hemorrhage. Journal of Therapeutic Ultrasound 2015 3(Suppl 1):O7.
Submit your next manuscript to BioMed Central and take full advantage of:

- Convenient online submission

- Thorough peer review

- No space constraints or color figure charges

- Immediate publication on acceptance

- Inclusion in PubMed, CAS, Scopus and Google Scholar

- Research which is freely available for redistribution
() Biomed Central

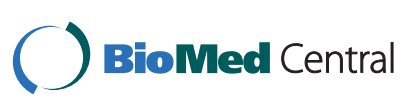

(c) 2015 Costa et al; licensee BioMed Central Ltd. This is an Open Access article distributed under the terms of the Creative Commons Attribution License (http://creativecommons.org/licenses/by/4.0), which permits unrestricted use, distribution, and reproduction in any medium, provided the original work is properly cited. The Creative Commons Public Domain Dedication waiver (http:// creativecommons.org/publicdomain/zero/1.0/) applies to the data made available in this article, unless otherwise stated. 